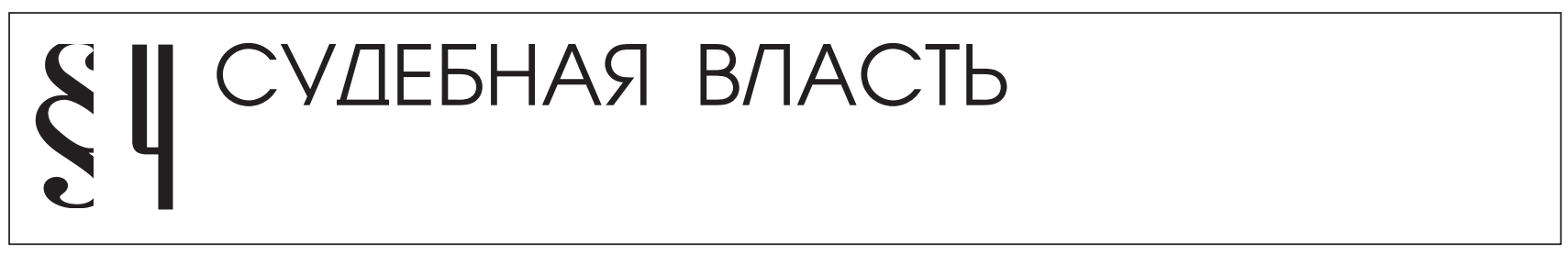

Карасев P.E.

\title{
КОНСТИТУЦИОННЫЙ СУД РФ: СРЕДСТВА ЗАЩИТЫ ПРАВ И СВОБОД ЧЕЛОВЕКА И ГРАЖДАНИНА
}

\begin{abstract}
Аннотация: Предметом исследования в настоящей статье выступают средства защиты прав и свобод человека игражданина в Конституционном Суде Российской Федерации, их отличительные черты и характерные особенности, а также проблемы, связанных применением указанных средств. Автором выделяются и рассматриваются три основных средства защиты прав и свобод в рамках процедур конкурентного и абстрактного конституционного контроля: подача конституиионнойжалобы, направление конституционного запроса судом, направление конституционного запросагосударственным органом или должностным личом. В процессе исследования автором использовались как общенаучные методы научного анализа, синтеза, так и специально-юридические методьл: сравнительно-правовой, метод толкования права. Научная новизна заключается в конкретизации и систематизации механизма защиты прав и свобод человека игражданина в порядке конституционного судопроизводства, в выводах автора о необходимости изменения действующих критериев допустимости конституционной жалобы, а также в выводах о наличии признаков опосредованности зашиты прав и свобод при рассмотрении конституционныхзапросов судов игосударственных органов (должностныхлии). Результаты исследования могут быть использованы в дальнейтем при изучении проблем судебной защиты прав и свобод человека и гражданина.

Abstract: The object of studies in this article involves the means of protection of basic rights and freedoms of individual and citizen in the Constitutional Court of the Russian Federation, their distinctive and characteristic features, as well as the problems regarding use of these means. The author singles out and evaluates three main means of protection of rights and freedoms within the procedures of competitive and abstract constitutional control: filing a constitutional claim, sending a constitutional request by a court, sending a constitutional request by a public body or a public official. In the process of studies the author used general scientific methods of analysis and synthesis, as well as special legal methods: comparative legal method, method of interpretation of law. Scientific novelty is due to the specification and systematization of the mechanism of protection of rights and freedoms of individual and citizen within the framework of the constitutional judicial proceedings, conclusions of the author regarding the need to change the existing criteria for admissibility of a constitutional complaint, as well as the conclusions regarding mediated character of protection of basic rights and freedoms when examining of constitutional requests of courts and public bodies and officials. The results of studies may be used in the further studies in the sphere of problems of protection of basic rights and freedoms of individual and citizen.
\end{abstract}

Ключевые слова: Конституционный Суд, Конституция, конституционныій контроль, судебная власть, права и свободы, судебная защита, жалоба, запрос, судопроизводство, правозащитная деятельность.

Keywords: the Constitutional Court, the Constitution, constitutional control, judicial power, judicial power, rights and freedoms, judicial protection, complaint, request, judicial proceedings, law-protection activity.

принятием Конституции Российской Федерации 1993 года у российских граждан появились законодательно закрепленные права и

\footnotetext{
${ }^{1}$ См.: Конституция Российской Федерации (принята всенародным голосованием 12.12.1993) (с учетом поправок, внесенных Законами РФ о поправках к Конституции РФ от 30.12.2008 N 6-ФКЗ, от 30.12.2008 N 7-ФК3) // Справочноправовая система «Консультант Плюс».
}

свободы, социальные возможности, гарантированные государством. Однако, не смотря на государственные гарантии, в законодательстве Российской Федерации и в практике применения права существуют, и время от времени проявляются определенные пробелы, неизбежно влекущие нарушения прав и свобод человека и гражданина. В этой связи вопрос защиты прав и свобод человека и гражданина все еще остается актуальным. Решение данного вопроса, по нашему мнению, должно 
быть одним из приоритетных направлений деятельности как государства в целом, так и Конституционного Суда Российской Федерации в частности, поскольку «признание и защита основных прав и свобод представляют собой фундаментальную основу конституционного строя и одновременно выступают необходимым элементом и основным условием всех происходящих общественных процессов. Конституционные ценности образуют системное единство и находятся в определенной иерархической соподчиненности»².

Конституционный Суд Российской Федерации является органом, который осуществляет судебную власть и установленные законом полномочия в целях защиты основ конституционного строя, основных прав и свобод человека и гражданина, обеспечения верховенства и прямого действия Конституции Российской Федерации на всей территории Российской Федерации ${ }^{3}$.

Правовой основой функционирования Конституционного Суда является Конституция Российской Федерации и Федеральный конституционный закон от 21.07.1994 N 1-ФКЗ «О Конституционном Суде Российской Федерации» (далее - Закон о Конституционном Суде).

Цели деятельности Суда достигаются посредством осуществления им конституционного контроля, под которым понимается любая форма проверки на соответствие конституции актов и действий органов публичной власти, а также общественных объединений, осуществляющих публичные функции или созданных (формально и/или фактически) для участия в осуществлении публичной власти ${ }^{4}$. Необходимо различать понятия «конституционный контроль» и «конституционный надзор». Как указывает С.А. Авакьян, «различие между конституционным контролем и конституционным надзором состоит прежде всего в силе соответствующих решений: орган конституционного контроля вправе либо отменить акт, либо объявить его утратившим силу; орган конституционного надзора сам не может

\footnotetext{
${ }^{2}$ Информация Конституционного Суда Российской Федерации «О конституционно-правовых аспектах совершенствования правотворческой и правоприменительной деятельности в сфере обеспечения и защиты прав и свобод граждан (на основе решений Конституционного Суда Российской Федерации 2009-2011 годов) URL: http://www.ksrf.ru/ru/Info/Maintenance/Informationks/Pages/ Aspect-KS.aspx (дата обращения: 01.02.2014).

${ }^{3}$ См.: Федеральный конституционный закон от 21.07.1994 N 1-ФКЗ (ред. от 28.12.2010) «О Конституционном Суде Российской Федерации» (с изм. и доп., вступающими в силу с 09.02.2011) // Справочно-правовая система «Консультант Плюс».

${ }^{4}$ См.: Конституционное (государственное) право зарубежных стран. В 4-х т. Т. 1-2 / Отв. ред. Б.А. Страшун. М.: Изд-во БЕК, 1996. C. 72.
}

этого сделать и только предлагает иным органам отменить акт, оцениваемый им как неконституционный»

Таким образом, особая социальная роль Конституционного Суда по сравнению с другими судебными органами заключается в наличии исключительного полномочия по рассмотрению дел о соответствии Конституции Российской Федерации федеральных законов и иных нормативно-правовых актов. Так, в соответствии с Постановлением Конституционного Суда РФ от 16.06.1998 N 19-П «По делу о толковании отдельных положений статей 125,126 и 127 Конституции Российской Федерации» «предусмотренное статьей 125 Конституции Российской Федерации полномочие по разрешению дел о соответствии Конституции Российской Федерации федеральных законов, нормативных актов Президента Российской Федерации, Совета Федерации, Государственной Думы, Правительства Российской Федерации, конституций республик, уставов, а также законов и иных нормативных актов субъектов Российской Федерации, изданных по вопросам, относящимся к ведению органов государственной власти Российской Федерации и совместному ведению органов государственной власти Российской Федерации и органов государственной власти субъектов Российской Федерации, относится к компетенции только Конституционного Суда Российской Федерации. По смыслу статей 125, 126 и 127 Конституции Российской Федерации, суды общей юрисдикции и арбитражные суды не могут признавать названные в ее статье 125 (пункты «а» и «б» части 2 и часть 4) акты не соответствующими Конституции Российской Федерации и потому утрачивающими юридическую силу» 6 .

Учитывая особую социальную роль Конституционного Суда Российской Федерации, на наш взгляд, уместно говорить об особых средствах защиты прав и свобод человека и гражданина в конституционном судопроизводстве, только для него характерных.

Толковый словарь русского языка определяет слово «средство»как прием, способ действия для осуществления, достижения чего-либо7. Представляется, что

\footnotetext{
${ }_{5}^{5}$ Авакьян С.A. Конституционное право России: Учеб. курс: В 2 т. M., 2005. T. 1. C. 593.

${ }^{6}$ Постановлениее Конституционного Суда РФ от 16.06.1998 N 19-П «По делу о толковании отдельных положений статей 125,126 и 127 Конституции Российской Федерации» // Справочно-правовая система «Консультант Плюс».

${ }^{7}$ Словарь русского языка: Ок. 53000 слов / С. И. Ожегов; Под общ ред. проф. Л. И. Скворцова. - 24-е изд., испр. - М.: ООО «Издательский дом «ОНИКС 21 век»: ООО «Издательство «Мир и Образование», 2004. С. 995.
} 


\section{Право и политика 4 (172) • 2014}

применительно к защите прав и свобод человека и гражданина в конституционном судопроизводстве целесообразно говорить о средствах такой защиты с позиции заинтересованных субъектов. К ним можно отнести непосредственно граждан и их объединения, а также государственные органы, наделенные полномочиям обращаться в Конституционный Суд с запросами о соответствии нормативно-правовых актов Конституции Российской Федерации (ч. ч. 2, 4 ст. 125 Конституции Российской Федерации). Необходимо отметить, что, в соответствии с позицией Суда, возможность защиты прав и свобод посредством конституционного правосудия должна быть обеспечена каждому, в том числе иностранным гражданам и лицам без гражданства, если законом нарушены их права и свободы, гарантированные Конституцией Российской Федерации ${ }^{8}$.

Думается, что одним из основных средств защиты прав и свобод человека и гражданина в Конституционном Суде является подача конституционной жалобы. Согласимся с мнением В.А. Кряжкова, что наделение Конституционного Суда полномочиями по разбирательству жалоб на нарушение конституционных прав граждан усилило защиту данных прав и подчеркнуло их конституционный уровень, стало одним из условий формирования к ним уважительного отношения 9 .

При рассмотрении конституционной жалобы осуществляется конкретный конституционный контроль, сущность которого заключается в рассмотрении дел о соответствии нормативно-правовых актов Конституции Российской Федерации по жалобам граждан на нарушения их конституционных прав и свобод. В рамках конкретного конституционного контроля осуществляется защита широкого круга прав и свобод человека и гражданина: личных, политических, экономических, социальных и трудовых. При подаче жалобы гражданин является инициатором судебного разбирательства, целью которого является (с позиции гражданина) устранение предполагаемого противоречия между нормой закона, подвергаемого контролю, и Конституцией Российской Федерации. Тем самым конституционная жалоба выступает средством устране-

\footnotetext{
${ }^{8}$ См.: Постановление Конституционного Суда РФ от 17.02 .1998 N 6-П «По делу о проверке конституционности положения части второй статьи 31 Закона СССР от 24 июня 1981 года «О правовом положении иностранных граждан в СССР» в связи с жалобой Яхья Дашти Гафура» // Справочно-правовая система «Консультант Плюс».

${ }^{9}$ Кряжков В.А. Российская модель конституционной жалобы // Конституционное и муниципальное право. 2012. N 5. С. 65 - 71. // Справочно-правовая система «Консультант Плюс».
}

ния социального противоречия между общественными интересами, закрепленными в Конституции Российской Федерации и интересами отдельных социальных групп, выраженными в законе ${ }^{10}$.

Конституционная жалоба может быть принята к рассмотрению только при условии ее соответствия критериям допустимости, сформулированным в статье 97 Закона о Конституционном Суде. Федеральным конституционным законом от 03.11.2010 N 7-ФКЗ «О внесении изменений в Федеральный конституционный закон «О Конституционном Суде Российской Федерации» ${ }^{11}$ данные критерии были существенно изменены: теперь конституционная жалоба признается допустимой только после завершения рассмотрения конкретного дела в суде. Как указывает Конституционный Суд в своем Определении от 23.04.2013 N 664-О «из права каждого на судебную защиту его прав и свобод, как оно сформулировано в статье 46 Конституции Российской Федерации, не следует возможность выбора гражданином по своему усмотрению любых способов и процедур судебной защиты, особенности которых применительно к отдельным видам судопроизводства и категориям дел определяются, исходя из Конституции Российской Федерации, ее статей 46 - 53, 118, 120, 123 и 125 128 , федеральными конституционными законами и федеральными законами. В силу названных конституционных положений недопустимо, чтобы конституционное судопроизводство использовалось как средство судебной защиты, заменяющее судопроизводство по гражданским, уголовным или административным

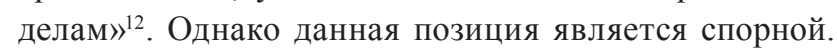
Как отмечает С.А. Авакьян «у заявителя, и прежде всего простого гражданина, по Конституции и прежней редакции ФКЗ было две возможности обратиться в Конституционный Суд, теперь осталась лишь одна» ${ }^{13}$. На наш взгляд, в данной законодатель-

\footnotetext{
${ }^{10}$ См.: URL: http://www.notariusy.ru/publisher/c33.htm (дата обращения: 03.02.2014 г.).

${ }^{11}$ Федеральный конституционный закон от 03.11.2010 N 7-ФКЗ «О внесении изменений в Федеральный конституционный закон «О Конституционном Суде Российской Федерации» // Справочноправовая система «Консультант Плюс».

${ }^{12}$ Определение Конституционного Суда РФ от 23.04.2013 N 664-О «Об отказе в принятии к рассмотрению жалобы гражданки Черепановой Инны Федоровны на нарушение ее конституционных прав пунктом 3 части первой статьи 3 , статьями 96 и 97 Федерального конституционного закона «О Конституционном Суде Российской Федерации» // Справочно-правовая система «Консультант Плюс».

${ }^{13}$ Авакьян С.A. Конституционный Суд Российской Федерации: неоднозначные законодательные новеллы // Конституционное и
} 
ной новелле можно усмотреть нарушение ч. 2 ст. 55 Конституции Российской Федерации, согласно которой «в Российской Федерации не должны издаваться законы, отменяющие или умаляющие права и свободы человека и гражданина». Данная норма является одной из гарантий полноты прав и свобод как с точки зрения их перечня, так и с точки зрения адекватности принимаемых законов конституционно установленным или международно признанным пределам прав и свобод человека и гражданина ${ }^{14}$. Представляется, что действующие критерии допустимости конституционной жалобы создают для заявителя дополнительные сложности, связанные с необходимостью завершения производства по делу в суде, а также с необходимостью обжалования решения суда. Кроме того, учитывая продолжительные сроки принятия к производству и рассмотрения конституционной жалобы, возникает проблема приостановления исполнения судебного решения в порядке ст. 98 Закона о Конституционном Суде: судебное постановление может быть исполнено еще до вынесения соответствующего судебного акта о приостановлении исполнения. Таким образом, по нашему мнению, с точки зрения обеспечения надлежащей защиты прав и свобод человека и гражданина, было бы целесообразно вернуться к предыдущей редакции статьи 97 Закона о Конституционном Суде, позволяющей заявителю подавать конституционную жалобу до окончания рассмотрения дела в суде.

Вторым, самостоятельным способом защиты прав и свобод человека и гражданина, на наш взгляд, является подача судами запросов о конституционности законов, подлежащих применению в конкретном деле. Данный элемент также следует отнести к конкретному конституционному контролю. В данном случае инициатором конституционного судебного процесса может являться судебный орган, пришедший к выводу о неконституционности закона, подлежащего применению в конкретном деле. Так, соответствии с уже упомянутым выше Постановлением Конституционного Суда РФ от 16.06.1998 N 19-П в случае, если суд приходит к такому выводу, у него возникает обязанность обратиться в Конституционный Суд с соответствующим запросом, поскольку не соответствующий Конституции Российской Федерации нормативно-правовой акт дол-

муниципальное право. 2011. N 1. С. 3 - 7. // Справочно-правовая система «Консультант Плюс».

${ }^{14}$ См.: «Комментарий к Конституции Российской Федерации» (постатейный) (2-е издание, пересмотренное) (под ред. В.Д. Зорькина) («Норма», «Инфра-М», 2011) // Справочно-правовая система «Консультант Плюс». жен быть лишен юридической силы в установленном порядке. Как указывает Конституционный Суд, данная обязанность судов вытекает из возложенного на них, как на независимые органы правосудия, конституционного полномочия обеспечивать судебную защиту прав и свобод человека, включая равенство перед законом и судом, подчиняясь при этом Конституции Российской Федерации и федеральному закону. Эта позиция нашла свое отражение и в Постановлении Пленума Верховного Суда Российской Федерации от 31 октября 1995 г. N 8 «О некоторых вопросах применения судами Конституции Российской Федерации при осуществлении правосудия» ${ }^{15}$. В первоначальной редакции данного документа разъяснялось, что суды, исходя из положений ч. 4 ст. 125 Конституции Российской Федерации, могут (а не обязаны) обращаться в Конституционный Суд ${ }^{16}$. Это создавало правовую неопределенность в вопросе защиты прав и свобод человека и гражданина, связанную с необязательностью судебного решения для других судов при рассмотрении дел. Впоследствии Пленумом Верховного Суда РФ была учтена позиция Конституционного Суда РФ: указанное Постановление было принято в новой редакции, констатирующей обязанность судов обращаться с соответствующими запросами в орган конституционного контроля при выявлении несоответствия законов Конституции Российской Федерации.

Таким образом, при проверке по запросам судов конституционности законов, подлежащих применению в конкретном деле защита прав и свобод человека и гражданина в порядке конституционного судопроизводства происходит без участия самого гражданина, то есть опосредованно: гражданин не является участником конституционного процесса; обращаясь в суд за защитой нарушенного права, гражданин, являясь лицом, участвующим в конкретном деле, не выступает инициатором возбуждения конституционного судопроизводства. Следовательно, «общее» социальное противоречие, связанное с неконституционностью закона, разрешается в конституционном судебном процессе, а конкретное право лица восстанавливается (защищается) в том суде, который обратился с запро-

\footnotetext{
${ }^{15}$ См.: Постановление Пленума Верховного Суда Российской Федерации от 31 октября 1995 г. N 8 «О некоторых вопросах применения судами Конституции Российской Федерации при осуществлении правосудия» // Справочно-правовая система «Консультант Плюс».

${ }^{16}$ См.: Особое мнение судьи Конституционного Суда Российской Федерации Г.А. Гаджиева по делу о толковании отдельных положений статей 125, 126 и 127 Конституции Российской Федерации» // Справочно-правовая система «Консультант Плюс».
} 
DOI: $10.7256 / 1811-9018.2014 .4 .11443$

При цитировании этой статьи сноска на доі обязательна

\section{Право и политика 4 (172) $\bullet 2014$}

сом в орган конституционного контроля в порядке соответствующего судопроизводства после вынесения судебного акта Конституционным Судом.

Еще одним способом защиты прав и свобод человека и гражданина в конституционном судопроизводстве, на наш взгляд, является рассмотрение дел по запросам государственных органов в порядке абстрактного нормоконтроля. В соответствии с ч. 2 ст. 125 Конституции РФ в Конституционный Суд с такими запросами вправе обращаться Президент Российской Федерации, Совет Федерации, Государственная Дума, члены Совета Федерации, депутаты Государственной Думы, Правительство Российской Федерации, Верховный Суд Российской Федерации, Высший Арбитражный Суд Российской Федерации, органы законодательной и исполнительной власти субъектов Российской Федерации. В данном случае защита прав и свобод человека и гражданина также осуществляется опосредованно. При рассмотрении дел данной категории отсутствует как таковой социальный конфликт между гражданином и государством. Направление государственным органом запроса в Конституционный Суд, на наш взгляд, может свидетельствовать об осуществлении государством в лице его органов самоконтроля, направленного на предупреждение возможных нарушений прав и свобод человека и гражданина. Как отмечает Т.Г. Морщакова, органы государственной власти не выступают в данном случае как субъекты, к которым применяются оспариваемые нормы, эти субъекты вне конкретного правоприменительного процесса могут просить проверить конституционность содержания того или иного регулирования. Лица государственной власти, уполномоченные на такое обращение, часто обжалуют нормативные предписания с той точки зрения, что приняты в нарушение статьи 55 Конституции и особенно ее части 3 , не допускающей никаких ограничений прав и свобод человека правовыми актами ниже уровня закона ${ }^{17}$. На наш взгляд, можно утверждать, что при подаче запроса в порядке ч. 2 ст. 125 Конституции Российской Федерации, государственные органы, должностные лица выполняют свою прямую функцию по защите прав и свобод человека и гражданина и предупреждению их нарушения, тем самым обеспечивая стабильность конституционного строя нашей страны.

${ }^{17}$ См.: Морщзакова Т.Г. Конституционный контроль в Российской Федерации URL: http://www.terralegis.org/terra/lek/lek_5.html (дата обращения: 07.02.2014 г.).
Подводя итог, необходимо отметить, что защита прав и свобод человека и гражданина в Конституционном Суде Российской Федерации может осуществляться как непосредственно по инициативе лица, чье право нарушено, так и по инициативе государственных органов или должностных лиц путем использования особых средств, таких как конституционная жалоба, конституционный запрос, в порядке как абстрактного, так и конкретного конституционного контроля. Значение такой защиты очень велико, поскольку решение Конституционного Суда, будучи общеобязательным, помогает оперативно устранить законодательные пробелы и неопределенности, из-за которых нарушаются права и свободы человека и гражданина. Не смотря на то, что конституционное судопроизводство не лишено недостатков, оно является сильным средством, помогающим восстанавливать нарушенные права и предупреждать их нарушения, поддерживая незыблемость основ конституционного строя в Российской Федерации.

\section{Библиография:}

1. Авакьян С.А. Конституционное право России: Учеб. курс: В 2 т. М., 2005. Т. 1.

2. Авакьян С.А. Конституционный Суд Российской Федерации: неоднозначные законодательные новеллы // Конституционное и муниципальное право. 2011. N 1. С. 3-7.

3. В.Д. Зорькин. Комментарий к Конституции Российской Федерации (постатейный) (2-е издание, пересмотренное) (под ред. В.Д. Зорькина) М.: «Норма», «Инфра-М», 2011.

4. Б.А. Страшун. Конституционное (государственное) право зарубежных стран. В 4-х т. Т. 1-2 / Отв. ред. Б.А. Страшун. М.: Изд-во БЕК, 1996.

5. Кряжков В.А. Российская модель конституционной жалобы // Конституционное и муниципальное право. 2012. N 5. С. 65-71.

6. Морщакова Т.Г. Конституционный контроль в Российской Федерации URL: http://www. terralegis.org/terra/lek/lek_5.html (дата обращения: 07.02.2014 г.).

7. Добрынин Н.М.. В юбилей о проблемах взаимосвязи и взаимообусловленности Конституции России и конституционализма: природа, реальность, специфика, миф // Право и политика. - 2013. - № 13. C. 104-107. DOI: 10.7256/1811-9018.2013.13.10181. 
8. Полянина А.К.. Принцип автономии личности в конституционномправе//Правоиполитика.-2013.-№ 13. - C. 104-107. DOI: 10.7256/1811-9018.2013.13.9824.

9. Соколов Т.В.. Решения и правовые позиции Конституционного Суда Российской Федерации: сущность, виды и соотношение // Право и политика. - 2013. - № 12. - С. 104-107. DOI: 10.7256/18119018.2013.12.10169.

10. Мильчакова О.В.. К вопросу о стадиях конституционного судебного процесса // Право и политика. - 2013. - № 12. - C. 104-107. DOI: 10.7256/18119018.2013.12.10382.

11. А. Д. Керимов, Е. В. Халипова. Правомерно ли выделение лишь трёх ветвей государственной власти? // Политика и Общество. - 2012. - № 3. - С. 104-107.

12. Корзина И.А.. Конституционное правосудие-механизм защиты прав местного самоуправления. // Административное и муниципальное право. - 2011. - № 3. - C. 104-107.

13. Е. А. Лукьянова. Крушение конституционных основ? // Право и политика. - 2011. - № 1.

14. Г. Х. Нуриев. Особенности европейской модели судебного конституционного контроля и их влияние на конституционное судопроизводство. // Политика и Общество. - 2010. - № 11.

15. Агеев В.Н. Правомерность ограничения прав и свобод государственных служащих в Российской Федерации: правовая оценка Конституционного Суда // NB: Вопросы права и политики. - 2013. 1. - C. 166-189. DOI: 10.7256/2305-9699.2013.1.394. URL: http://www.e-notabene.ru/lr/article_394.html

16. Щербанюк O.В. Суверенитет народа как гарантия прав и свобод человека и гражданина // NB: Вопросы права и политики. - 2013. - 10. - С. 131-148. DOI: 10.7256/2305-9699.2013.10.9610. URL: http:// www.e-notabene.ru/lr/article_9610.html

17. Мильчакова О.В. Конституционное правосудие на страже прав и свобод человека и гражданина // Политика и Общество.-2013.-12.-C. 1528-1536. DOI: 10.7256/1812-8696.2013.12.10446.

18. Карасев Р.Е. Конституционный Суд РФ: защита прав и свобод человека и гражданина в законодательном процессе // Право и политика. - 2013. - 12.C. 1614-1617. DOI: 10.7256/1811-9018.2013.12.10391.

\section{References (transliteration):}

1. Avak'yan S.A. Konstitutsionnoe pravo Rossii: Ucheb. kurs: V 2 t. M., 2005. T. 1.
2. Avak'yan S.A. Konstitutsionnyi Sud Rossiiskoi Federatsii: neodnoznachnye zakonodatel'nye novelly // Konstitutsionnoe i munitsipal'noe pravo. 2011. N 1. S. 3-7.

3. V.D. Zor'kin. Kommentarii k Konstitutsii Rossiiskoi Federatsii (postateinyi) (2-e izdanie, peresmotrennoe) (pod red. V.D. Zor'kina) M.: «Norma», «Infra-M», 2011.

4. B.A. Strashun. Konstitutsionnoe (gosudarstvennoe) pravo zarubezhnykh stran. V 4-kh t. T. 1-2 / Otv. red. B.A. Strashun. M.: Izd-vo BEK, 1996.

5. Kryazhkov V.A. Rossiiskaya model' konstitutsionnoi zhaloby // Konstitutsionnoe i munitsipal'noe pravo. 2012. N 5. S. 65-71.

6. Morshchakova T.G. Konstitutsionnyi kontrol' v Rossiiskoi Federatsii URL: http://www.terralegis. org/terra/lek/lek_5.html (data obrashcheniya: 07.02.2014 g.).

7. Dobrynin N.M.. V yubilei o problemakh vzaimosvyazi i vzaimoobuslovlennosti Konstitutsii Rossii i konstitutsionalizma: priroda, real'nost', spetsifika, mif // Pravo i politika. - 2013. - № 13. - S. 104-107. DOI: 10.7256/1811-9018.2013.13.10181.

8. Polyanina A.K.. Printsip avtonomii lichnosti v konstitutsionnom prave // Pravo i politika. - 2013. - № 13. - S. 104-107. DOI: 10.7256/1811-9018.2013.13.9824.

9. Sokolov T.V.. Resheniya i pravovye pozitsii Konstitutsionnogo Suda Rossiiskoi Federatsii: sushchnost', vidy i sootnoshenie // Pravo i politika. - 2013. - № 12. - S. 104-107. DOI: 10.7256/1811-9018.2013.12.10169.

10. Mil'chakova O.V.. K voprosu o stadiyakh konstitutsionnogo sudebnogo protsessa // Pravo i politika. - 2013. - № 12. - S. 104-107. DOI: 10.7256/18119018.2013.12.10382.

11. A. D. Kerimov, E. V. Khalipova. Pravomerno li vydelenie lish' trekh vetvei gosudarstvennoi vlasti? // Politika i Obshchestvo. - 2012. - № 3. - S. 104-107.

12. Korzina I.A.. Konstitutsionnoe pravosudie-mekhanizm zashchity prav mestnogo samoupravleniya. // Administrativnoe i munitsipal'noe pravo. - 2011. - № 3. - S. 104-107.

13. E. A. Luk'yanova. Krushenie konstitutsionnykh osnov? // Pravo i politika. - 2011. - № 1.

14. G. Kh. Nuriev. Osobennosti evropeiskoi modeli sudebnogo konstitutsionnogo kontrolya i ikh vliyanie na konstitutsionnoe sudoproizvodstvo. // Politika i Obshchestvo. - 2010. - № 11.

15. Ageev V.N. Pravomernost' ogranicheniya prav i svobod gosudarstvennykh sluzhashchikh v Rossiiskoi Federatsii: pravovaya otsenka Konstitutsionnogo Suda 
DOI: $10.7256 / 1811-9018.2014 .4 .11443$

При цитировании этой статьи сноска на dоі обязательна

\section{Право и политика 4 (172) 2014}

// NB: Voprosy prava i politiki. - 2013. - 1. - C. 166189. DOI: 10.7256/2305-9699.2013.1.394. URL: http:// www.e-notabene.ru/lr/article_394.html

16. Shcherbanyuk O.V. Suverenitet naroda kak garantiya prav i svobod cheloveka i grazhdanina // NB: Voprosy prava i politiki. -2013 . -10 . - C. 131-148. DOI: 10.7256/2305-9699.2013.10.9610. URL: http://www.enotabene.ru/lr/article_9610.html
17. Mil'chakova O.V. Konstitutsionnoe pravosudie na strazhe prav i svobod cheloveka i grazhdanina // Politika i Obshchestvo. - 2013. - 12. - C. 1528-1536. DOI: $10.7256 / 1812-8696.2013 .12 .10446$.

18. Karasev R.E. Konstitutsionnyi Sud RF: zashchita prav i svobod cheloveka i grazhdanina $\mathrm{v}$ zakonodatel'nom protsesse // Pravo i politika. - 2013. - 12. - C. 1614-1617. DOI: 10.7256/1811-9018.2013.12.10391. 